\title{
Evolutionary Genetics of Borrelia
}

\author{
Zachary J. Oppler ${ }^{1 *}$, Kayleigh R. O’Keeffe ${ }^{1}$, Karen D. McCoy² and Dustin Brisson'1 \\ ${ }^{1}$ Department of Biology, University of Pennsylvania, 433 South University Ave, Philadelphia, PA 19104, USA \\ ${ }^{2}$ Centre for Research on the Ecology and Evolution of Diseases (CREES), MiVEGEC, University of Montpellier - \\ CNRS - IRD, Montpellier, France \\ *Corresponding author: zoppler@sas.upenn.edu
}

DOI: https://doi.org/10.21775/cimb.042.097

\begin{abstract}
The genus Borrelia consists of evolutionarily and genetically diverse bacterial species that cause a variety of diseases in humans and domestic animals. These vector-borne spirochetes can be classified into two major evolutionary groups, the Lyme borreliosis clade and the relapsing fever clade, both of which have complex transmission cycles during which they interact with multiple host species and arthropod vectors. Molecular, ecological, and evolutionary studies have each provided significant contributions towards our understanding of the natural history, biology and evolutionary genetics of Borrelia species; however, integration of these studies is required to identify the evolutionary causes and consequences of the genetic variation within and among Borrelia species. For example, molecular and genetic studies have identified the adaptations that maximize fitness components throughout the Borrelia lifecycle and enhance transmission efficacy but provide limited insights into the evolutionary pressures that have produced them. Ecological studies can identify interactions between Borrelia species and the vertebrate hosts and arthropod vectors they encounter and the resulting impact on the geographic distribution and abundance of spirochetes but not the genetic or molecular basis underlying these interactions. In this review we discuss recent findings on the evolutionary genetics from both of the evolutionarily distinct clades of Borrelia species. We focus on connecting molecular interactions to the ecological processes that have driven the evolution and diversification of Borrelia species in order to understand the current distribution of genetic and molecular variation within and between Borrelia species.
\end{abstract}

\section{Introduction}

Zoonotic pathogens, like those that comprise the Borrelia genus, are a major cause of emerging and re-emerging infectious diseases worldwide and constitute a significant threat to public health (Jones et al., 1994; Taylor et al., 2001). Like many of the bacterial and viral species that cause zoonotic diseases, most Borrelia species have complex transmission cycles in which they interact with multiple vertebrate hosts and vectors over the course of their life cycles (Taylor et al., 2001; Lloyd-Smith et al., 2009; Huang et al., 2019). The bacterial spirochetes belonging to the genus Borrelia are vectored by arthropods and infect a wide range of vertebrate hosts; many cause diseases in humans and domestic animals (Burgdorfer et al., 1982; Parker and White, 1992; Pritt et al., 2016), please see Radolf and Samuels (2021). Species within the genus Borrelia are classified into two major evolutionary groups, the Lyme borreliosis clade (LB) and the relapsing fever clade (RF). Members of the Lyme borreliosis clade are vectored exclusively by hard-bodied ticks in the Ixodes genus and have been investigated to a much greater depth than members of the relapsing fever clade, most of which are vectored by soft-bodied Argasid ticks. Although these divergent evolutionary clades recently have been proposed as separate genera (Adeolu and Gupta, 2014), we will continue to refer to them as the Lyme borreliosis clade and the relapsing fever clade until the new classifications have additional consensus (Adeolu and Gupta, 2014; Barbour et al., 2017; Margos et al., 2017, 2020). In this article, we review the ecological interactions underlying the evolutionary forces that have produced the current distribution of genetic and genomic variation in both the LB and RF Borrelia clades (Table 1). In addition, we focus on the evolutionary and ecological 
Table 1

\begin{tabular}{|c|c|c|c|c|}
\hline & & All Borrelia & Lyme Borrelia & RF Borrelia \\
\hline \multirow{3}{*}{ Vector } & $\begin{array}{c}\text { Vector } \\
\text { specialization }\end{array}$ & $\begin{array}{l}\text { - Geographic range shaped by } \\
\text { vector associations (Margos et } \\
\text { al., 2011, 2019a) } \\
\text { - Vector switch can result in genetic } \\
\text { divergence among } \\
\text { subpopulations, expansion into } \\
\text { novel geographic range (Lescot et } \\
\text { al., 2008; Gatzmann et al., 2015; } \\
\text { Becker et al., 2016) }\end{array}$ & $\begin{array}{l}\text { - Characterized molecular factors } \\
\text { contributing to tick specialization and } \\
\text { persistence (e.g. ospA) (Pal et al., 2004; } \\
\text { Battisti et al., 2008; Konnai et al., 2012) } \\
\text { - Long feeding time of Ixodid ticks provides } \\
\text { opportunities for migration and gene flow } \\
\text { (Sonenshine, 1979; Margos et al., 2011; } \\
\text { Vollmer et al., 2011b; Norte et al., 2020b) } \\
\text { - Rate and direction of gene flow only } \\
\text { weakly correlated with that of ticks (Walter } \\
\text { et al., 2017) }\end{array}$ & $\begin{array}{l}\text { - Transovarial } \\
\text { transmission in some } \\
\text { species, although } \\
\text { molecular mechanisms } \\
\text { poorly characterized } \\
\text { (Barbour and Hayes, } \\
\text { 1986; Cutler, 2010; } \\
\text { Rollend et al., 2013) } \\
\text { - Short feeding time of } \\
\text { Argasid ticks limits } \\
\text { opportunities for } \\
\text { migration and gene flow } \\
\text { (Vial et al., 2006; Vial, } \\
\text { 2009) }\end{array}$ \\
\hline & $\begin{array}{l}\text { Life inside } \\
\text { vector } \\
\text { environment }\end{array}$ & $\begin{array}{l}\text { - Exposure to environmental } \\
\text { conditions experienced by vectors } \\
\text { (Kung et al., 2013) }\end{array}$ & $\begin{array}{l}\text { - Many genes regulated in temperature- } \\
\text { dependent manner likely due to exposure } \\
\text { to fluctuating environmental conditions in } \\
\text { hard Ixodid ticks (Ojaimi et al., 2003; } \\
\text { Tokarz et al., 2004; Popitsch et al., 2017; } \\
\text { Phelan et al., 2019) }\end{array}$ & $\begin{array}{l}\text { - Sheltered microhabitats } \\
\text { of Argasid ticks allow } \\
\text { spirochetes to survive } \\
\text { and remain infectious } \\
\text { for several years } \\
\text { (Francis, 1938) }\end{array}$ \\
\hline & $\begin{array}{l}\text { Microbial } \\
\text { interactions } \\
\text { within the } \\
\text { vector }\end{array}$ & $\begin{array}{l}\text { - Limited number of genes involved } \\
\text { in interbacterial interaction } \\
\text { pathways owing to limited density } \\
\text { and diversity of resident microbial } \\
\text { communities in ticks (Ross et al., } \\
\text { 2018; Couper et al., 2019) }\end{array}$ & $\begin{array}{l}\text { - Frequent coinfection with other human } \\
\text { pathogens (Hersh et al., 2014; Diuk- } \\
\text { Wasser et al., 2016; Moutailler et al., } \\
\text { 2016; Ross et al., 2018) } \\
\text { - Competition with coinfecting strains } \\
\text { reduces spirochete load in ticks (Rego et } \\
\text { al., 2014; Moutailler et al., 2016; Walter et } \\
\text { al., 2016; Durand et al., 2017; Genne et } \\
\text { al., 2018; Genné et al., 2019) }\end{array}$ & $\begin{array}{l}\text { - Limited data have been } \\
\text { collected on } \\
\text { coinfections of RF } \\
\text { Borrelia with } \\
\text { conspecific strains or } \\
\text { other human pathogens }\end{array}$ \\
\hline \multirow[t]{2}{*}{ Host } & $\begin{array}{c}\text { Host } \\
\text { specialization }\end{array}$ & $\begin{array}{l}\text { - Limited data have been collected } \\
\text { on host associations within RF } \\
\text { species, so it is unknown if the } \\
\text { molecular mechanisms or } \\
\text { evolutionary genetic impacts } \\
\text { found among LB species apply to } \\
\text { RF Borrelia species }\end{array}$ & $\begin{array}{l}\text { - Well characterized genetic and molecular } \\
\text { mechanisms contributing to host } \\
\text { specialization (e.g. CspA, OspC, OspE, } \\
\text { etc.) (Marconi et al., 1993; Livey et al., } \\
\text { 1995; Lagal et al., 2006; Önder et al., } \\
\text { 2012; Hammerschmidt et al., 2014b; Hart } \\
\text { et al., 2018; Tufts et al., 2019; Lin et al., } \\
\text { 2020) } \\
\text { - Limited HGT among species with different } \\
\text { host associations (Jacquot et al., 2014) } \\
\text { - Host associations shape population } \\
\text { genetic structure (e.g. bird-associated } \\
\text { species have much less genetic structure } \\
\text { than rodent-associated species) (Victorino } \\
\text { et al., 2008; Vollmer et al., 2011b, 2013; } \\
\text { Šimo et al., 2017; Norte et al., 2020b) } \\
\text { - Host switch results in genetic divergence } \\
\text { among subpopulations, expansion into } \\
\text { novel geographic range (Margos et al., } \\
\text { 2009; Becker et al., 2016) } \\
\text { - Wide geographic range of vectors permits } \\
\text { hosts to drive changes in geographic } \\
\text { range (Stanek et al., 2012; Šimo et al., } \\
\text { 2017) } \\
\text { Diverse host communities maintain genetic } \\
\text { diversity of Borrelia populations (Brisson } \\
\text { and Dykhuizen, 2004; Mechai et al., 2016; } \\
\text { Vuong et al., 2017) }\end{array}$ & $\begin{array}{l}\text { - Limited geographic } \\
\text { range of vectors limits } \\
\text { extent to which hosts } \\
\text { can drive changes in } \\
\text { geographic range (Vial, } \\
\text { 2009; Trape et al., } \\
\text { 2013) }\end{array}$ \\
\hline & $\begin{array}{l}\text { Interactions } \\
\text { with host } \\
\text { immune } \\
\text { system }\end{array}$ & $\begin{array}{l}\text { - Host immune memory drives } \\
\text { negative frequency dependent } \\
\text { selection on Borrelia populations } \\
\text { (Marcsisin et al., 2016; Gomez- } \\
\text { Chamorro et al., 2019) } \\
\text { - Well characterized genetic and } \\
\text { molecular mechanisms that } \\
\text { enable rapid immune evasion } \\
\text { within the host (Zhang and Norris, } \\
\text { 1998; Barbour et al., 2006; Coutte } \\
\text { et al., 2009; Graves et al., 2013; } \\
\text { Norris, 2015) }\end{array}$ & $\begin{array}{l}\text { - vlsE system generates antigenic } \\
\text { variability to evade host immunity (Zhang } \\
\text { and Norris, 1998; Coutte et al., 2009; } \\
\text { Graves et al., 2013; Norris, 2015; Tufts et } \\
\text { al., 2019) }\end{array}$ & $\begin{array}{l}\text { - Vmp system generates } \\
\text { antigenic variability to } \\
\text { evade host immunity } \\
\text { (Barbour et al., 2006) }\end{array}$ \\
\hline
\end{tabular}


consequences arising from these past evolutionary changes.

Our current understanding of the evolutionary genetics of Borrelia species can be informed by investigations into the ecological interactions encountered by Borrelia species during their life cycle. These interactions are the product of past evolutionary processes that have shaped the observable genotypic and phenotypic diversity. Many investigations have focused separately on either the evolutionary history or the ecology of several Borrelia species, both of which have been invaluable to our understanding of the biology and history of Borrelia. Studies focusing on the evolutionary history of Borrelia have detailed genetic and phenotypic variation across space and among host species, genetic and genomic diversity and divergence as well as the processes occurring over millennia that have resulted in the variation within and between species observed today (De Michelis et al., 2000; Dykhuizen et al., 2008; Graves et al., 2013; Coipan et al., 2018). These evolutionary patterns and processes have resulted in molecular factors associated with host and vector specialization or mechanisms of escaping immune responses, differences in the rates and processes leading to diversification, and the identification of virulence factors that enhance survival or transmission (Pal et al., 2001; Fingerle et al., 2007; Neelakanta et al., 2007; de Silva et al., 2009; Kenedy et al., 2012; Ogden et al., 2015; Tufts et al., 2019); many of these factors are directly linked to host and vector specialization. Ecological studies have, on the other hand, characterized processes and interactions affecting the distribution and abundance of Borrelia species (Paul et al., 2016; Kilpatrick et al., 2017; Vuong et al., 2017). Connecting these ecological processes and interactions with the resulting evolutionary adaptations can reveal how these evolutionary changes have shaped and will continue to shape current and future ecological interactions and species distributions.

The common ancestor of all Borrelia species appears to be an obligate parasite that interacted exclusively with or within vector and host environments. Thus, vectors and hosts constitute the selective environment to which Borrelia must adapt to maximize survival and transmission efficacy (Haven et al., 2011). The disparate selective pressures experienced by species of Borrelia or populations within a species that interact with different vector or host species have resulted in divergent molecular adaptations that can lead to increased specialization on a subset of vectors or hosts. In many cases, the increased specialization feeds back, increasing selective pressures on other molecules to increase the efficacy of their interactions with molecules in some hosts or vectors at the cost of decreasing interaction efficacy in other host or vector species (Wang et al., 2001; Tufts et al., 2019). Associations with a limited subset of host or vector species further drive micro-evolutionary changes in Borrelia populations and species by shaping patterns of gene flow and geographic distributions (McCoy et al., 2013; Khatchikian et al., 2015; Seifert et al., 2015) as well as altering the effects of genetic drift and mutation (Brisson et al., 2012).

Investigating the complex web of ecological interactions among Borrelia, their vectors, and their hosts, facilitates detection of both the selective pressures that have given rise to the present-day genetic variation and the downstream evolutionary changes that are a product of that variation. Although the evolutionary and ecological history of Lyme borreliae have been the subject of extensive investigation (Kurtenbach et al., 2006; Margos et al., 2011; Brisson et al., 2012; Ogden et al., 2015; Kilpatrick et al., 2017), significantly less research has focused on the relapsing fever group (Cutler, 2010; Talagrand-Reboul et al., 2018). Here, we synthesize and compare recent findings on the evolutionary genetics from both groups of Borrelia, with a focus on identifying ecological processes that have driven adaptations and the current distribution of genetic variants within and between Borrelia species and the evolutionary consequences of that variation. Understanding the feedbacks between the evolution of these species and their ecological interactions is critical for predicting and controlling future disease epidemics.

\section{Interactions between Borrelia and their vectors} Evolutionary impact of vector specialization All Borrelia species depend on at least one vector species for the completion of their life cycle. Interactions between Borrelia and its vectors select for molecules that enable successful uptake from infected hosts, persistence within the vector, migration through vector tissues, and transmission and persistence in subsequent vertebrate hosts (Pal et al., 2001; Fingerle et al., 2007; Neelakanta et al., 2007; de Silva et al., 2009; Kenedy et al., 2012). Additionally, many RF Borrelia species have 
molecular machinery that enables transovarial transmission (Barbour and Hayes, 1986; Cutler, 2010; Rollend et al., 2013), although these molecules are not well characterized. For example, all studied LB species express the Outer Surface Protein A (OspA) which binds to the Ixodid tick midgut receptor, TROSPA, and enables colonization and persistence within the tick (Pal et al., 2004; Battisti et al., 2008). Borrelia specializing on different tick species experience different selective pressures at the molecular level owing to variation in tick proteins (like TROSPA) that Borrelia must exploit to complete its enzootic cycle (Konnai et al., 2012). That is, different tick environments impose different selective regimes on Borrelia traits, resulting in refinement by natural selection to maximize efficacy of each Borrelia species in a single vector species (Couper et al., 2020). The molecular variants resulting from this natural selection create variation in vector competence and vector specialization which further influences downstream interactions between Borrelia and vertebrate hosts. Molecules mediating persistence and specialization of RF Borrelia species within vectors have not been investigated to a similar depth. Nevertheless, most LB and RF Borrelia species are transmitted by a single species or related group of ticks such that the genes that mediate these interactions are expected to vary little within Borrelia species (Wilske et al., 1993; Eisen, 2020).

Vector associations are important drivers of the geographic range and migration rates of Borrelia species (Margos et al., 2011, 2019a). Variation in home ranges and rates of gene flow among Borrelia species can be attributed both to the feeding patterns of their vectors and to the range and mobility of host species parasitized by their vectors (Vial et al., 2006; Vial, 2009; Margos et al., 2011; Vollmer et al., 2011a; Stanek et al., 2012; Trape et al., 2013; Norte et al., 2020a). As an adaptation to their endophilic lifestyle, Argasid ticks like Ornithodoros sonrai typically take rapid bloodmeals to avoid predators and exposure to harsh environmental conditions outside of their sheltered microhabitats (Vial, 2009). Shorter feeding times in combination with feeding preferentially on territorial, burrowing vertebrates significantly constrains opportunities for migration and gene flow of both $O$. sonrai and $B$. crocidurae, the RF species that it vectors (Vial et al., 2006). Geographically isolated subpopulations of many RF Borrelia species vectored by ticks that parasitize less-mobile host species are genetically divergent due to both neutral evolution and to natural selection favoring specialization to local environmental conditions (Vial et al., 2006; Hoen et al., 2009; Humphrey et al., 2010). In contrast, Ixodid ticks remain attached to their hosts for several days and some, like I. dentatus or $I$. uriae, preferentially feed on mobile host species like birds (Sonenshine, 1979; Eveleigh and Threlfall, 1974.). LB species associated with vectors that feed on highly-mobile host species exhibit limited population genetic structure as a result of frequent migration among subpopulations (Margos et al., 2011; Vollmer et al., 2011b; Gómez-Díaz et al, 2011). Although these Borrelia species may experience a wider range of ecological interactions with more diverse host communities, they rarely show divergent features across their geographic range (Norte et al., 2020b). Thus, despite experiencing more diverse ecological interactions, Borrelia species with broad geographic ranges tend to harbor less genetic variation than Borrelia species exposed to fewer ecological interactions due to the homogenizing effect of gene flow among subpopulations.

Borrelia that colonize a novel vector species are exposed to different selective pressures derived from distinct ecological interactions in dissimilar geographic ranges. This can result in genetic divergence between populations of the same Borrelia species vectored by different arthropod species. For example, as populations of the RF species $B$. duttonii adapted to the body louse, Pediculus humanus, they diverged from the ancestral populations vectored by O. moubata (Lescot et al., 2008). Following this vector switch, the louse-borne populations experienced a massive geographic expansion due to their close association with human populations. Further, genetic data revealed sufficient evolutionary divergence and genome degradation to classify these populations as a distinct species, $B$. recurrentis (Lescot et al., 2008). Similarly, a vector switch by $B$. bavariensis from $I$. persulcatus to $I$. ricinus provided an opportunity for the Borrelia species to expand into Europe (Gatzmann et al., 2015; Becker et al., 2016). Vector switching not only allows Borrelia species to invade novel ecological niches, the resulting genomic diversification can result in speciation.

Despite the generally tight associations between Borrelia and their vectors, the direction and rate of gene flow of Borrelia species typically correlates only weakly with those of their vectors at fine temporal and geographic scales (Walter et al., 2017). This is at least partially due to the fact that vertebrate hosts frequently transport Borrelia spirochetes in the 

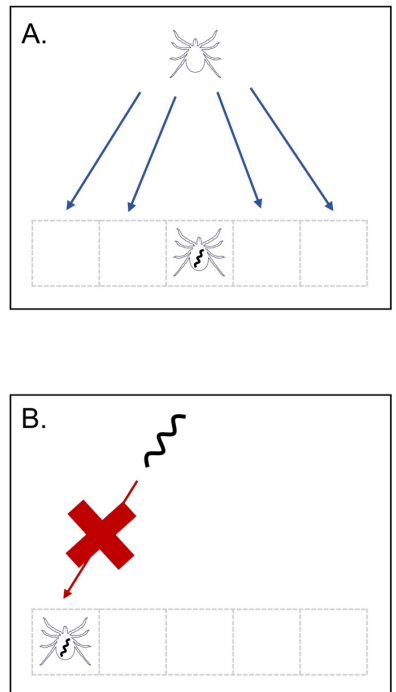
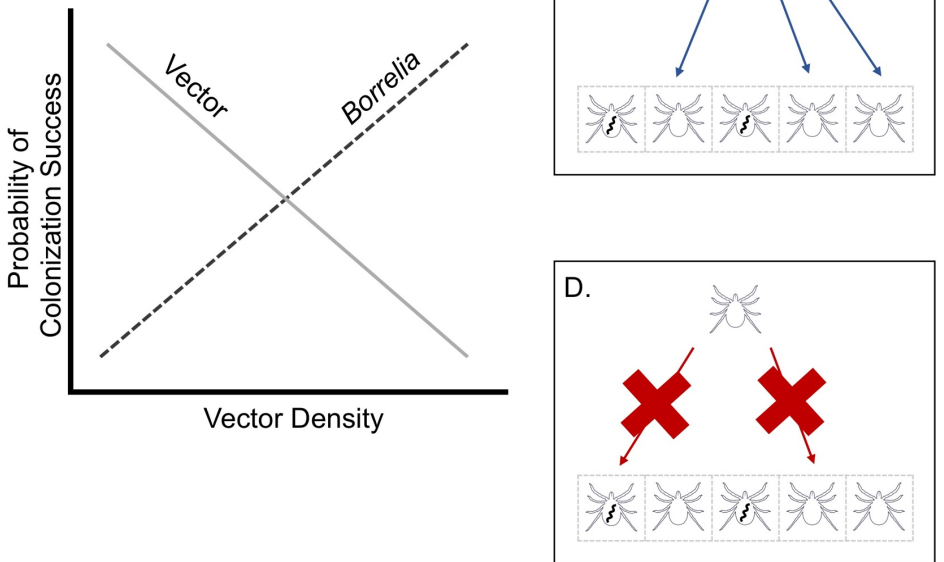

Figure 1. Differences in the rates of gene flow between Borrelia and their vectors may be impacted by differences in colonization efficiency. The rate at which Borrelia species and their vectors colonize new sites could be dependent, in part, on the size of the resident vector population. A. Vectors dispersing into areas with small resident vector populations may colonize with high efficiency due to limited competition with resident vectors if intraspecies competition imparts colonization efficiency, B. while migrant Borrelia spirochetes are likely to colonize with low efficiency in these areas due to the limited opportunities for transmission. C. By contrast, there are many transmission opportunities for Borrelia at locations with large vector populations that could result in higher colonization efficiency, D. whereas large resident vector populations could limit the probability that dispersing ticks will colonize due to competition with resident vectors. These differences in colonization efficiencies between Borrelia and their vectors, mediated by the size of resident vector populations, may have contributed to the observed differences in the rate and direction of gene flow between Borrelia species and their primary vectors. Additional research on the impact of intraspecies competition on population dynamics and colonization efficiency is necessary to determine the impacts of competition on the evolutionary history of both Borrelia and vector species.

absence of their vectors and vice versa. Namely, infected hosts can transport Borrelia even when they are not being parasitized by vectors, and uninfected hosts can transport uninfected vectors in the absence of Borrelia. For example, while soft ticks like $O$. turicata typically take short blood meals and have limited inter-burrow movement, $B$. turicatae-infected hosts may easily migrate between burrows (Adeyeye and Butler, 1989). and leave their bacteria in a new location. Likewise, population genetic structure among circulating $B$. garinii strains has been shown to correlate strongly with the local genetic structure of their tick vector $I$. uriae that diverge into distinct host races exploiting different sympatric seabird species at the scale of a colony (McCoy et al. 2013). However, no structure in $B$. garinii strains is evident at the scale of the ocean basin due to the large-scale movements and local colonization dynamics of the bacterium with the seabird host (Gómez-Díaz et al. 2011). The rates and direction of gene flow may differ between Borrelia species and vectors even if they disperse together because the bacterium and vector colonize locations at different efficiencies (Figure 1). That is, Borrelia may colonize new sites with high efficiency when the local density of vectors is high, while competition with resident vectors may limit the efficiency by which immigrating vectors can establish at these new sites. Additional work is needed to reveal how migration within vertebrates and differential colonization efficiencies contribute to the observed differences in the rate and direction of gene flow between Borrelia and their vectors (Walter et al., 2017). 
Evolutionary genetic consequences arising from interactions with the vector environment and coinfecting pathogens

The evolutionary genetics of Borrelia populations are shaped by many of the environmental features experienced by their vectors. Survival of Borrelia within non-homeothermic ticks poses a significant challenge owing to exposure to daily and seasonal temperature fluctuations in addition to the physiological changes caused by environmental fluctuations (Kung et al., 2013). Experimental evidence from other bacterial species has demonstrated that fluctuating conditions select for microbes that are tolerant of a wider range of environments due to the strong selective pressure for tolerance resulting from extreme environmental variation (Chevin and Hoffmann, 2017; Saarinen et al., 2018). The extraordinary environmental fluctuations with which Borrelia interacts have even led some to hypothesize that Borrelia may have adapted to infect vertebrate hosts as a means of escaping environmentally hostile conditions that negatively impact vector populations (Cutler, 2010). Interestingly, RF Borrelia species vectored by nidicolous ticks have been shown to survive and remain infectious within unfed ticks for several years, possibly owing to the fact that their vectors predominantly reside within burrows, caves, and human and livestock habitats, buffered against environmental fluctuations (Francıs, 1938). By contrast, all LB species within Ixodid ticks remain exposed to environmental extremes of both the summers and winters in temperate climates and experimental studies have shown that LB survival in ticks may strongly decline at high temperatures (Shih et al, 1995). Understanding the mechanisms by which Borrelia withstand wide-ranging environmental fluctuations may provide insights into how recent and future changes in climate will ultimately impact their geographic distribution and evolutionary trajectories.

Borrelia and other microbes within their vectors may facilitate or compromise one another's ability to colonize, grow, and be transmitted to hosts (DiukWasser et al., 2016; Moutailler et al., 2016; Ross et al., 2018). For example, several Borrelia species have been found to co-occur with a variety of other human pathogens, including the causal agent of human babesiosis, Babesia microti (Diuk-Wasser et al., 2016). B. burgdorferi sensu stricto (Bbss) is thought to facilitate $B$. microti within tick vectors as the number of ticks coinfected with these two pathogens is higher than would be expected by chance (Hersh et al., 2014; Diuk-Wasser et al., 2016). Coincidentally, the range and prevalence of $B$. microti has increased significantly in the northeastern United States where Bbss was already highly prevalent, suggesting important epidemiological consequences of this interaction (Dunn et al., 2014; Diuk-Wasser et al., 2016). However, for now, it remains unknown as to whether interactions between these pathogens within the tick vector are neutral or positive nor whether $B$. microti may reciprocally facilitate Bbss transmission. Further work on the nature of interactions between co-infecting infectious agents in the tick vector is now needed to better understand the role of the vector in determining the epidemiological dynamics of co-infecting pathogens.

Borrelia may also encounter other Borrelia species or conspecific strains within their vectors (Moutailler et al., 2016). Ticks infected by multiple strains of LB species have the same overall spirochete load as single-strain infections, suggesting there is competition among coinfecting strains which results in lower infection intensity on each strain within a tick (Walter et al., 2016; Durand et al., 2017; Genne et al., 2018; Genné et al., 2019). Since Borrelia density within ticks positively correlates with the probability of successful transmission to vertebrate hosts (Rego et al., 2014), competition among coinfecting strains is expected to reduce the evolutionary fitness of each strain. While inter-strain competition is expected to select for traits like increased growth rates or the production of spiteful molecules to suppress the growth of other strains (Cattadori et al., 2008; Telfer et al., 2010; Alizon et al., 2013; Susi et al., 2015), there is no evidence from genomic surveys nor from controlled experiments that such traits have evolved. More work is needed to identify the evolutionary consequences of interactions between co-infecting strains, both within vectors and within vertebrate hosts.

The limited density and diversity of microbial communities that naturally reside within Ixodid ticks seems likely to exert only minimal selective pressure on Borrelia species (Ross et al., 2018). Contrary to initial reports of a highly diverse Ixodid microbiome (van Treuren et al., 2015; Zolnik et al., 2016; Abraham et al., 2017), recent studies controlling for bacterial biomass demonstrated that the diversity of tick microbiomes is actually quite low (Ross et al., 2018; Couper et al., 2019). Recent investigations of both LB and RF Borrelia genomes revealed far fewer genes known to be involved in interbacterial 

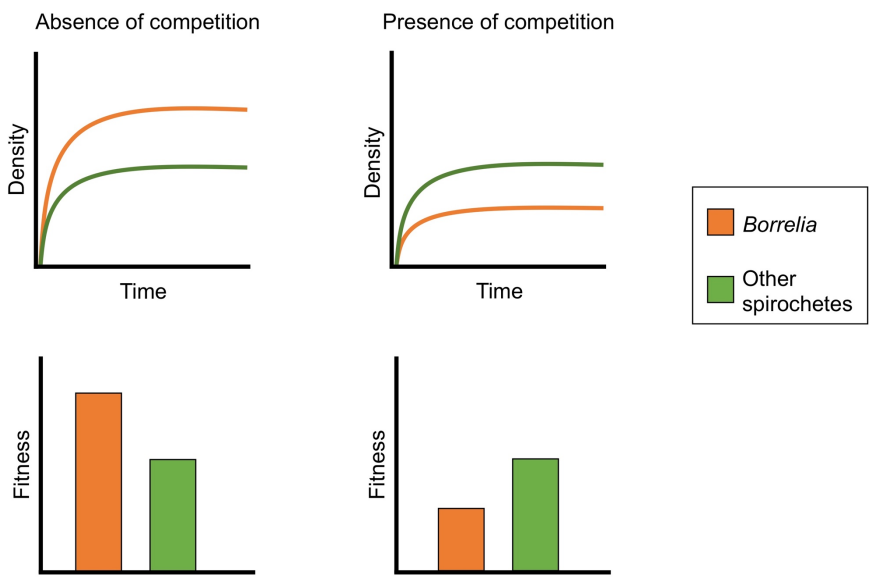

Figure 2. The presence and absence of genes involved in interbacterial interactions may have current and future fitness consequences. Many spirochetes have maintained genetic pathways for the production of molecules involved in interbacterial interaction. Most of these pathways have been lost in Borrelia species, likely because Borrelia rarely encounter rich microbiota within hosts or vectors that can reduce the fitness of Borrelia through competitive interactions. In the absence of competitive interbacterial interactions, the metabolic costs associated with the production of interbacterialinteraction molecules may result in negative fitness consequences for producers. The evolved loss of these interbacterial interaction pathways in Borrelia resulted in an increase in fitness in the absence of competition with other microbes in low diversity environments $(\mathbf{A})$. In the presence of competition with other microbes (B), producers should be relatively more fit than non-producers as interbacterial interaction products provide a competitive advantage that offsets the metabolic costs of producing spiteful molecules; non-producers like Borrelia suffer fitness consequences as a result of their limited competitive abilities in higher diversity environments. The negative fitness consequences experienced by non-producers, like Borrelia, in higher microbial diversity environments may limit their ability to survive in novel environments where they are likely to encounter novel microbial species.

interaction pathways than have been found in many other surveyed bacterial species (Ross et al., 2018). Genes mediating interactions with other microbes likely have been lost in Borrelia owing to their limited encounters with other microbes and consequently weak natural selection for their maintenance (Zhang et al., 2012; Ross et al., 2018). This limited number of genes utilized for interbacterial interactions is likely to have negative fitness consequences for Borrelia species that engage in novel ecological interactions with microbes within new vectors or host species as geographic ranges change due to changes in climate or human land use (Figure 2).

\section{Interactions between Borrelia and vertebrate hosts}

Genetic basis and evolutionary consequences of host specialization

Interactions between Borrelia and their vertebrate hosts, similar to Borrelia-vector interactions, underlie selective regimes that favor a set of finely-tuned molecular mechanisms. These include molecules that enable vector-to-host transmission, colonization and spread to distal vertebrate tissues, evasion of the host immune system, and transmission back to the feeding vector (Kenedy et al., 2012; Ogden et al., 2015; Tufts et al., 2019). Borrelia species that interact with different sets of host species experience different selective pressures at the molecular level owing to variation in vertebrate immune components and other host molecules with which Borrelia must interact to complete its enzootic cycle (Roberts et al., 1998; Hammerschmidt et al., 2014a; Hart et al., 2018; Tufts et al., 2019). The sequence variation and molecular determinants of host associations in the LB group have been studied at much greater depth than those in the RF group, although it is likely that similar processes have occurred in both groups. Among LB species, even minor genetic differences between orthologous proteins can substantially impact resulting interactions with vertebrate host molecules. For example, molecular divergence at the complement regulator acquiring surface protein $A$ (CspA) results in differential ability to bind immune components and establish infection within various vertebrate species (Hart et al., 2018; Lin et al., 2020). 
The genetic sequences and related molecular processes in each Borrelia species ultimately feedback to shape the strength and frequency of subsequent interactions between Borrelia and the vertebrate host community which then impacts their geographic distribution, population genetic structure, and ensuing opportunities for interactions.

Host associations occur when vertebrate host species are infected more often than expected given their frequency in the host community. These associations are common among both LB and RF Borrelia species and are even emerging among Borrelia species previously considered to be host generalists (Hanincová et al., 2006; Kurtenbach et al., 2006; Mechai et al., 2016). For example, while Bbss infects a wide range of vertebrate species, individual strains clearly have host associations, as they do not all colonize and survive within the full range of vertebrate hosts (Anderson et al., 1990; Barthold et al., 1991; Norris et al., 1995; Wang et al., 2002; Barbour et al., 2009; Baum et al., 2012; Chan et al., 2012), and they vary in their capacity to infect and cause disease in humans (Dykhuizen et al., 2008; Wormser et al., 2008; Hanincova et al., 2013). The sequence variation among vertebrate species at molecules such as plasminogen and complement regulator proteins, molecules with which Bbss must interact to successfully colonize a host, limits the range of host species each Bbss strain can infect (Ripoche et al., 1988). As a result, sequence variation among Bbss strains at the molecules mediating these interactions, like OspC and OspE, produce species-specific differences in binding efficacy to plasminogen and complement regulator molecules (Lagal et al., 2006; Önder et al., 2012; Tufts et al., 2019). Since each Bbss strain maintains just a single OspC sequence, it can effectively bind plasminogen from only a narrow range of host species (Marconi et al., 1993; Livey et al., 1995; Casjens et al., 2018). The strong selective pressure to maximize efficacy of immune evasion imposes a major barrier to the long-term maintenance of host generalism in Borrelia.

The evolution of host associations is shaped by the strength and frequency of interactions between each Borrelia species, or individual strains within species, and each vertebrate species during its evolutionary history. As noted above, variation in host immune components creates disparate selective pressures for invading Borrelia species (Brisson and Dykhuizen, 2004; Bäumler and Fang, 2013). Hosts which are frequently infected and from which Borrelia achieve high host-to-tick transmission rates exert significantly stronger selective pressure than hosts that Borrelia rarely encounter or from which Borrelia are rarely transmitted to feeding ticks (Ripoche et al., 1988; Tufts et al., 2019). Among both LB and RF Borrelia species, the frequency of interactions with each vertebrate host is heavily influenced by the range and feeding preferences of their primary vectors (Margos et al., 2011; Talagrand-Reboul et al., 2018). As a Borrelia species or strain becomes increasingly welladapted to survive and transmit from a particular host species, its ability to survive and transmit from other vertebrate species tends to diminish, constraining downstream ecological interactions (Anderson et al., 1990; Barthold et al., 1991; Norris et al., 1995; Wang et al., 2001, 2002; Barbour et al., 2009; Baum et al., 2012; Chan et al., 2012; Tufts et al., 2019).

While host associations limit the geographic range of Borrelia species and constrain the range of ecological interactions, adaptation to novel host species - often termed a host range expansion or a host switch - can expand the diversity and range of ecological interactions Borrelia experience. This has resulted in genetic divergence and even speciation among LB species. Novel host species can impose distinct selective pressures while also providing opportunities for expansion of geographic range and alternate routes and rates of gene flow. For example, evolutionary divergence between the sister species $B$. garinii and $B$. bavariensis likely resulted from the evolution of different host associations, with $B$. garinii specializing on birds and $B$. bavariensis specializing on small mammals (Margos et al., 2009; Becker et al., 2016). The divergent selective regimes imposed by the different sets of vertebrates infected by each species, along with neutral evolutionary divergence in populations isolated in different sets of host species, led to in the genetic differentiation and speciation among these specialized LB species.

Genetic differentiation among Borrelia adapted to different host species is a product of both a reduction in gene flow and alternate selective pressures. That is, opportunities for genetic exchange among Borrelia species with different host associations will be limited by a lack of proximity as members of different Borrelia species are rarely found infecting the same host (Dykhuizen and Baranton, 2001; Bunikis et al., 2004). In fact, rates of horizontal gene transfer among LB species are 50 times lower than the rates of horizontal gene transfer among strains within LB 
species (Jacquot et al., 2014), possibly as a result of limited proximity of different Borrelia species associated with different host species which can result in different Borrelia species infecting different individual ticks (Hildebrandt et al., 2003; Brisson and Dykhuizen, 2006; Herrmann et al., 2013). Borrelia species also experience very limited selective pressure from vertebrate species that they encounter infrequently or those to which they are not welladapted and thus are not competent reservoirs. The lack of selective pressure to maintain the genetic and molecular variants necessary for a Borrelia species to infect these non-reservoir vertebrate host species eliminates evolutionary constraints, allowing specialization on the limited set of species that serve as regular hosts (Kurtenbach et al., 2006; Becker et al., 2016; Margos et al., 2019b). This positive feedback loop, along with the limited homogenizing effect of horizontal gene transfer among Borrelia species, has likely contributed to the high frequency of Borrelia species that utilize only a limited set of vertebrate species to complete their enzootic cycles.

Host associations shape the distribution and population genetic structure of Borrelia species

Vertebrate migration patterns shape the population genetic structure and geographic distribution of LB species. LB associated with small rodents and other less mobile host species tend to have well-defined population genetic structure as a result of limited opportunities for gene flow between isolated subpopulations (Victorino et al., 2008; Vollmer et al., 2011b; Norte et al., 2020b). In contrast, LB associated with highly-mobile host species, like birds, have limited population genetic structure and few distinct subpopulations as host movement and migration facilitate genetic exchange between geographically distant regions (Norte et al., 2020b). For example, population genetic structure can be observed even at very fine spatial scales for the rodent-associated $B$. afzelii, whereas genetic structure only began to emerge at inter-continental scales for the bird-associated $B$. valaisiana and $B$. garinii (Vollmer et al., 2011b, 2013; Gómez-Díaz et al., 2011). Thus, Borrelia species associated with mobile host species maintain genetic cohesion across their geographic range, while Borrelia associated with less mobile host species become genetically fragmented as a result of natural selection and adaptation to local conditions or host communities as well as genetic drift within the small effective subpopulations (Vollmer et al., 2011b; Norte et al., 2020b).
The extent to which vertebrate hosts can drive changes in the geographic range of Borrelia species is, of course, dependent upon the geographic distribution of competent vector species. As infected Ixodid ticks feed for up to several days (Šimo et al., 2017), they have many opportunities to migrate in tandem with the vertebrate hosts to which they are attached. On the other hand, most Argasid ticks detach from their hosts within minutes, limiting the opportunities to migrate to new sites on their hosts (Vial, 2009). As expected, Argasid ticks seem to have more constrained geographic ranges than their Ixodid relatives (Stanek et al., 2012; Trape et al., 2013), but ecological data on this tick family is still fragmentary. Since all Borrelia species depend on both vectors and vertebrate hosts for the completion of their enzootic cycle, the limited range and faster feeding time of Argasid vectors likely limits the opportunities for vertebrates to drive geographic range expansion of RF Borrelia species.

Interactions with diverse host species can promote the maintenance of genetic diversity within Borrelia populations. For example, many strains of Bbss coexist at geographic locations where the vertebrate community is highly diverse (Brisson and Dykhuizen, 2004). This is because antigenically distinct Bbss strains differ in their ability to successfully infect and be transmitted from each vertebrate species and no strain has the highest evolutionary fitness in all of the vertebrate species (Brisson and Dykhuizen, 2004; Cobey and Lipsitch, 2012). Variation among Bbss strains in host associations drives niche separation by allowing different subtypes to maximize transmission success in different hosts, thereby reducing within-host competition between strains (Brisson and Dykhuizen, 2004; Hanincová et al., 2006; Mechai et al., 2016; Vuong et al., 2017; Brisson, 2018). The presence of a diverse host community can thus promote and maintain an array of genetically divergent subtypes over the long-term.

Evolutionary genetic consequences arising from interactions with the vertebrate immune system Interactions between Borrelia and the vertebrate adaptive immune system drive natural selection for antigenic variability. The selective pressure for Borrelia to persist within its host for the duration necessary to be transmitted back to another feeding vector has resulted in the evolution of genetic and molecular mechanisms that enable immune evasion with sufficient variation to remain effective throughout a months- or years-long infection (Tufts et al., 2019). 
As infection proceeds, genetic loci encoding the immunodominant surface proteins $\mathrm{Vmp}$ in $\mathrm{RF}$ Borrelia species and Vmp-like sequences (VIsE) in LB species undergo frequent recombination with silent cassettes, generating novel antigens that are unrecognized by the host immune system (Zhang and Norris, 1998; Barbour et al., 2006; Coutte et al., 2009; Graves et al., 2013; Norris, 2015). Further, the genetic sequences at the silent cassettes evolve much more rapidly than the genes at other loci. This is due in part to the conservation of highly-mutable tandem repeat structures in the otherwise highlydiverged cassettes, suggesting that the ability to continuously generate novel sequence variation at this locus provides a significant fitness advantage (Lawrenz et al., 2004; Bankhead and Chaconas, 2007; Graves et al., 2013).

The adaptive immune systems of infected vertebrates also may drive balancing selection contributing to the maintenance of genetic diversity within Borrelia populations. For example, immune memory can create negative frequency dependent selection on Borrelia populations if rare genotypes have a selective advantage over common genotypes due to prior infections in the host community. That is, if immune memory to specific genotypes protects hosts from future infections of the same genotype but does not prevent infection with alternate genotypes, rare genotypes will have a selective advantage over more common genotypes. The underlying immune mechanisms necessary for negative frequency dependent selection to operate in natural populations have considerable empirical support in both RF and LB Borrelia species (Preac-Mursic et al., 1992; Gilmore et al., 1996; Probert et al., 1997; Barthold, 1999; Marcsisin et al., 2016). For example, mice previously infected with $B$. hermsii or $B$. burgdorferi were shown to be immune to antigenically homologous strains, but remained susceptible to infection by antigenically distinct strains (Probert et al., 1997; Marcsisin et al., 2016). Further, a recent study demonstrated that $B$. afzelii strain-specific antibodies can also be passed from mother to offspring, suggesting that the effects of immune memory may last beyond a single generation (Gomez-Chamorro et al., 2019). This type of negative frequency dependent process may enable antigenically distinct strains to be maintained within Borrelia populations, although no direct empirical evidence of this process operating in natural populations has been reported despite laboratory evidence that the underlying immune mechanisms necessary to select for rare genotypes are present in several natural host species (Preac-Mursic et al., 1992; Gilmore et al., 1996; Probert et al., 1997; Barthold, 1999; Marcsisin et al., 2016).

\section{Concluding remarks}

In this review, we summarized recent findings on the evolutionary genetics of both LB and RF Borrelia species. While we show that much work has been done to elucidate the biology and natural history of Borrelia, it is clear that there are still open questions about the causes and consequences of evolutionary change in these species, many of which are poised to be answered by leveraging existing knowledge on molecular mechanisms and ecological interactions. For example, molecular studies have played a critical role in identifying the mechanisms utilized by several Borrelia species to establish infection, evade immune responses, and transmit between hosts and vectors (Pal et al., 2001; Fingerle et al., 2007; Neelakanta et al., 2007; de Silva et al., 2009; Kenedy et al., 2012; Ogden et al., 2015; Tufts et al., 2019). Investigations incorporating the ecological interactions between species and their hosts and vectors have revealed the selective pressures that have given rise to the observable variation in the genetic and molecular components underlying these mechanisms (De Michelis et al., 2000; Dykhuizen et al., 2008; Graves et al., 2013; Coipan et al., 2018). Further, ecological and genetic studies have revealed how variation in these molecular mechanisms has continued to shape Borrelia evolution, driving changes in gene flow and geographic distribution, and altering the effects of genetic drift and mutation (Brisson et al., 2012; Khatchikian et al., 2015; Seifert et al., 2015). By integrating these studies, we can move beyond cataloging variation in molecular mechanisms and ecological relationships and understand how these factors are a consequence of historical evolutionary processes and how they will continue to drive evolutionary change.

Uncovering the evolutionary genetics of a system depends critically on a firm understanding of the molecular mechanisms and ecological interactions of the species being studied. While these aspects of Borrelia have been the subject of extensive investigation in many LB species, they remain to be investigated in even a single RF Borrelia species despite their greater diversity and medical importance worldwide (Table 1). For example, little is known about the molecular and genetic underpinnings of vector or host associations in any 
RF species nor the pattern or causes of population genetic structure, both of which have been central to studies of many LB species. Investigations into the molecular mechanisms and the genetic underpinnings of those mechanisms from a range of RF Borrelia species will permit many questions about the evolutionary genetics of RF species to be addressed. Comparing evolutionary processes among species and among the LB and RF clades will provide a better understanding of the interactions and constraints that have led to the current assemblage of species and diversity of characteristics that are observable today. Without these data, identifying the major drivers of evolution in these species will remain a significant challenge.

\section{References}

Abraham, N.M., Liu, L., Jutras, B.L., Yadav, A.K., Narasimhan, S., Gopalakrishnan, V., Ansari, J.M., Jefferson, K.K., Cava, F., JacobsWagner, C., and Fikrig, E. (2017). Pathogen-mediated manipulation of arthropod microbiota to promote infection. Proc. Natl. Acad. Sci. U.S.A. 114, E781-E790 DOI: 10.1073/pnas.1613422114

Adeolu, M., and Gupta, R.S. (2014). A phylogenomic and molecular marker based proposal for the division of the genus Borrelia into two genera: the emended genus Borrelia containing only the members of the relapsing fever Borrelia, and the genus Borreliella gen. nov. containing the members of the Lyme disease Borrelia (Borrelia burgdorferi sensu lato complex). Antonie Van Leeuwenhoek 105, 1049-1072. DOI: 10.1007/s10482-014-0164-x

Adeyeye, O.A., and Butler, J.F. (1989). Population structure and seasonal intra-burrow movement of Ornithodoros turicata (Acari: Argasidae) in gopher tortoise burrows. J. Med. Entomol. 26, 279-283. DOI: 10.1093/jmedent/26.4.279

Alizon, S., de Roode, J.C., and Michalakis, Y. (2013). Multiple infections and the evolution of virulence. Ecol. Lett. 16, 556-567. DOI: 10.1111/ ele. 12076

Anderson, J.F., Barthold, S.W., and Magnarelli, L.A. (1990). Infectious but nonpathogenic isolate of Borrelia burgdorferi. J. Clin. Microbiol. 28, 2693-2699 DOI: 10.1128/JCM.28.12.2693-2699.1990

Bankhead, T., and Chaconas, G. (2007). The role of VIsE antigenic variation in the Lyme disease spirochete: persistence through a mechanism that differs from other pathogens. Mol. Microbiol. 65, 1547-1558. DOI: 10.1111/j.1365-2958.2007.05895.x

Barbour, A.G., Adeolu, M., and Gupta, R.S. (2017). Division of the genus Borrelia into two genera (corresponding to Lyme disease and relapsing fever groups) reflects their genetic and phenotypic distinctiveness and will lead to a better understanding of these two groups of microbes (Margos et al. (2016) There is inadequate evidence to support the division of the genus Borrelia. Int. J. Syst. Evol. Microbiol.) Int. J. Syst. Evol. Microbiol. 67, 2058-2067. DOI: 10.1099/ijsem.0.001815

Barbour, A.G., Bunikis, J., Travinsky, B., Hoen, A.G., Diuk-Wasser, M.A., Fish, D., and Tsao, J.I. (2009). Niche partitioning of Borrelia burgdorferi and Borrelia miyamotoi in the same tick vector and mammalian reservoir species. Am. J. Trop. Med. Hyg. 81, 1120-1131. DOI: 10.4269/ajtmh.2009.09-0208

Barbour, A.G., Dai, Q., Restrepo, B.I., Stoenner, H.G., and Frank, S.A. (2006). Pathogen escape from host immunity by a genome program for antigenic variation. Proc. Natl. Acad. Sci. U.S.A. 103, 18290-18295 DOI: 10.1073/pnas.0605302103
Barbour, A.G., and Hayes, S.F. (1986). Biology of Borrelia species. Microbiol. Rev. 50, 381-400.

Barthold, S.W. (1999). Specificity of infection-induced immunity among Borrelia burgdorferi sensu lato species. Infect. Immun. 67, 36-42 DOI: 10.1128/IAI.67.1.36-42.1999

Barthold, S.W., Persing, D.H., Armstrong, A.L., and Peeples, R.A. (1991). Kinetics of Borrelia burgdorferi dissemination and evolution of disease after intradermal inoculation of mice. Am. J. Pathol. 139, 263-273.

Battisti, J.M., Bono, J.L., Rosa, P.A., Schrumpf, M.E., Schwan, T.G., and Policastro, P.F. (2008). Outer surface protein A protects Lyme disease spirochetes from acquired host immunity in the tick vector. Infect. Immun. 76, 5228-5237 DOI: 10.1128/IAl.00410-08

Baum, E., Hue, F., and Barbour, A.G. (2012). Experimental infections of the reservoir species Peromyscus leucopus with diverse strains of Borrelia burgdorferi, a Lyme disease agent. Mbio 3, e00434-12 DOI: 10.1128/mBio.00434-12

Baumler, A., and Fang, F.C. (2013). Host specificity of bacterial pathogens. Cold Spring Harb Perspect. Med. 3, a010041 DOI: 10.1101/cshperspect.a010041

Becker, N.S., Margos, G., Blum, H., Krebs, S., Graf, A., Lane, R.S., Castillo-Ramírez, S., Sing, A., and Fingerle, V. (2016). Recurrent evolution of host and vector association in bacteria of the Borrelia burgdorferi sensu lato species complex. BMC Genomics 17, 734. DOI: 10.1186/s12864-016-3016-4

Brisson, D. (2018). Negative frequency-dependent selection is frequently confounding. Frontiers in Ecology and Evolution 6, 10. DOI: 10.3389/fevo.2018.00010

Brisson, D., Drecktrah, D., Eggers, C.H., and Samuels, D.S. (2012). Genetics of Borrelia burgdorferi. Annu. Rev. Genet. 46, 515-536. DOI: 10.1146/annurev-genet-011112-112140

Brisson, D., and Dykhuizen, D.E. (2006). A modest model explains the distribution and abundance of Borrelia burgdorferi strains. Am. J. Trop. Med. Hyg. 74, 615-622. DOI: 10.4269/ajtmh.2006.74.615

Brisson, D., and Dykhuizen, D.E. (2004). ospC diversity in Borrelia burgdorferi: different hosts are different niches. Genetics 168, 713-722 DOI: 10.1534/genetics.104.028738

Bunikis, J., Garpmo, U., Tsao, J., Berglund, J., Fish, D., and Barbour, A.G. (2004). Sequence typing reveals extensive strain diversity of the Lyme borreliosis agents Borrelia burgdorferi in North America and Borrelia afzelii in Europe. Microbiology 150, 1741-1755. DOI: 10.1099/mic.0.26944-0

Burgdorfer, W., Barbour, A.G., Hayes, S.F., Benach, J.L., Grunwaldt, E. and Davis, J.P. (1982). Lyme disease-a tick-borne spirochetosis? Science 216, 1317-1319 DOl: 10.1126/science.7043737

Casjens, S.R., Di, L., Akther, S., Mongodin, E.F., Luft, B.J., Schutzer, S.E., Fraser, C.M., and Qiu, W. (2018). Primordial origin and diversification of plasmids in Lyme disease agent bacteria. BMC Genomics 19, 1-24. DOI: 10.1186/s12864-018-4597-x

Cattadori, I., Boag, B., and Hudson, P.J. (2008). Parasite co-infection and interaction as drivers of host heterogeneity. Int. J. Parasitol. 38, 371-380. DOI: 10.1016/j.jpara.2007.08.004

Chan, K., Awan, M., Barthold, S.W., and Parveen, N. (2012). Comparative molecular analyses of Borrelia burgdorferi sensu stricto strains B31 and N40D10/E9 and determination of their pathogenicity. BMC Microbiology 12, 157. DOI: 10.1186/1471-2180-12-157

Chevin, L., and Hoffmann, A.A. (2017). Evolution of phenotypic plasticity in extreme environments. Philosophical Transactions of the Royal Society B: Biological Sciences 372, 20160138. DOI: 10.1098/rstb. 2016.0138

Cobey, S., and Lipsitch, M. (2012). Niche and neutral effects of acquired immunity permit coexistence of pneumococcal serotypes. Science 335, 1376-1380 DOI: 10.1126/science.1215947

Coipan, C.E., van Duijvendijk, G.L., Hofmeester, T.R., Takumi, K., and Sprong, $H$. (2018). The genetic diversity of Borrelia afzelii is not 
maintained by the diversity of the rodent hosts. Parasites \& Vectors 11, 454. DOI: 10.1186/s13071-018-3006-2

Couper, L.I., Kwan, J.Y., Ma, J., and Swei, A. (2019). Drivers and patterns of microbial community assembly in a Lyme disease vector. Ecology and Evolution 9, 7768-7779. DOI: 10.1002/ece3.5361

Couper, L.I., Yang, Y., Yang, X.F., and Swei, A. (2020). Comparative vector competence of North American Lyme disease vectors. Parasites \& Vectors 13, 29. DOI: 10.1186/s13071-020-3893-x

Coutte, L., Botkin, D.J., Gao, L., and Norris, S.J. (2009). Detailed analysis of sequence changes occurring during vlsE antigenic variation in the mouse model of Borrelia burgdorferi infection. PLoS Pathog 5, e1000293. DOI: 10.1371/journal.ppat. 1000293

Cutler, S. (2010). Relapsing fever-a forgotten disease revealed. J. Appl. Microbiol. 108, 1115-1122. DOI: 10.1111/j.1365-2672.2009.04598.x

De Michelis, S., Sewell, H.S., Collares-Pereira, M., Santos-Reis, M., Schouls, L.M., Benes, V., Holmes, E.C., and Kurtenbach, K. (2000). Genetic diversity of Borrelia burgdorferi sensu lato in ticks from mainland Portugal. J. Clin. Microbiol. 38, 2128-2133. DOI: 10.1128/ JCM.38.6.2128-2133.2000

de Silva, A.M., Tyson, K.R., and Pal, U. (2009). Molecular characterization of the tick-Borrelia interface. Front. Biosci. (Landmark Ed) 14, 3051-3063 DOI: 10.2741/3434

Diuk-Wasser, M.A., Vannier, E., and Krause, P.J. (2016). Coinfection by Ixodes tick-borne pathogens: ecological, epidemiological, and clinical consequences. Trends Parasitol. 32, 30-42. DOI: 10.1016/j.pt. 2015.09.008

Dunn, J.M., Krause, P.J., Davis, S., Vannier, E.G., Fitzpatrick, M.C., Rollend, L., Belperron, A.A., Stacey, A., Bockenstedt, L.K., and Fish, D. (2014). Borrelia burgdorferi promotes the establishment of Babesia microti in the northeastern United States. PLoS One 9, e115494. DOl: 10.1371/journal.pone.0115494

Durand, J., Herrmann, C., Genne, D., Sarr, A., Gern, L., and Voordouw, M.J. (2017). Multistrain infections with Lyme borreliosis pathogens in the tick vector. Appl. Environ. Microbiol. 83, e02552-16 DOI: 10.1128/ AEM.02552-16

Dykhuizen, D.E., and Baranton, G. (2001). The implications of a low rate of horizontal transfer in Borrelia. Trends Microbiol. 9, 344-350. DOl: 10.1016/S0966-842X(01)02066-2

Dykhuizen, D.E., Brisson, D., Sandigursky, S., Wormser, G.P., Nowakowski, J., Nadelman, R.B., and Schwartz, I. (2008). The propensity of different Borrelia burgdorferi sensu stricto genotypes to cause disseminated infections in humans. Am. J. Trop. Med. Hyg. 78, 806-810. DOI: 10.4269/aitmh.2008.78.806

Eisen, L. (2020). Vector competence studies with hard ticks and Borrelia burgdorferi sensu lato spirochetes: A review. Ticks and Tickborne Diseases 11: 101359 DOI: 10.1016/j.ttbdis.2019.101359

Eveleigh, E.S., and Threlfall, W. (1974). The biology of Ixodes (Ceratixodes) uriae White, 1852 in Newfoundland. Acarologia 16: 62135.

Fingerle, V., Goettner, G., Gern, L., Wilske, B., and Schulte-Spechtel, U. (2007). Complementation of a Borrelia afzelii OspC mutant highlights the crucial role of OspC for dissemination of Borrelia afzelii in Ixodes ricinus. International Journal of Medical Microbiology 297, 97-107. DOI: 10.1016/j.jimm.2006.11.003

FrancIs, E. (1938). Longevity of the tick Ornithodoros turicata and of Spirochaeta recurrentis within this tick. Public Health Reports (1896-1970) 2220-2241. DOI: 10.2307/4582740

Gatzmann, F., Metzler, D., Krebs, S., Blum, H., Sing, A., Takano, A., Kawabata, H., Fingerle, V., Margos, G., and Becker, N.S. (2015). NGS population genetics analyses reveal divergent evolution of a Lyme Borreliosis agent in Europe and Asia. Ticks and Tick-Borne Diseases 6. 344-351. DOI: 10.1016/j.ttbdis.2015.02.008

Genné, D., Sarr, A., Gomez-Chamorro, A., Durand, J., Cayol, C., Rais, O., and Voordouw, M.J. (2018). Competition between strains of
Borrelia afzelii inside the rodent host and the tick vector. Proceedings of the Royal Society B 285, 20181804. DOI: $10.1098 / \mathrm{rspb} .2018 .1804$

Genné, D., Sarr, A., Rais, O., and Voordouw, M.J. (2019). Competition between strains of Borrelia afzelii in immature Ixodes ricinus ticks is not affected by season. Frontiers in Cellular and Infection Microbiology 9, 431. DOI: 10.3389/fcimb.2019.00431

Gilmore, R.D., Jr, Kappel, K.J., Dolan, M.C., Burkot, T.R., and Johnson, B.J. (1996). Outer surface protein C (OspC), but not P39, is a protective immunogen against a tick-transmitted Borrelia burgdorferi challenge: evidence for a conformational protective epitope in OspC. Infect. Immun. 64, 2234-2239 DOI: 10.1128/iai.64.6.2234-2239.1996

Gomez-Chamorro, A., Battilotti, F., Cayol, C., Mappes, T., Koskela, E., Boulanger, N., Genné, D., Sarr, A., and Voordouw, M.J. (2019). Susceptibility to infection with Borrelia afzelii and TLR2 polymorphism in a wild reservoir host. Scientific Reports 9, 1-12. DOI: 10.1038/ s41598-019-43160-3

Gómez-Díaz, E., Boulinier, T., Sertour, N., Cornet, M., Ferquel, E., and McCoy, K.D. (2011) Genetic structure of marine Borrelia garinii and population admixture with the terrestrial cycle of Lyme borreliosis. Environmental Microbiology 13: 245367 DOI: 10.1111/j. 1462-2920.2011.02515

Gómez-Díaz, E., Jordà, M., Peinado, M.A., and Rivero, A. (2012). Epigenetics of host-pathogen interactions: the road ahead and the road behind. PLoS Pathog 8, e1003007. DOI: 10.1371/journal.ppat. 1003007

Graves, C.J., Ros, V.I., Stevenson, B., Sniegowski, P.D., and Brisson, D. (2013). Natural selection promotes antigenic evolvability. PLOS Pathog 9, e1003766. DOI: 10.1371/journal.ppat.1003766

Hammerschmidt, C., Koenigs, A., Siegel, C., Hallstrom, T., Skerka, C., Wallich, R., Zipfel, P.F., and Kraiczy, P. (2014). Versatile roles of CspA orthologs in complement inactivation of serum-resistant Lyme disease spirochetes. Infect. Immun. 82, 380-392 DOI: 10.1128/IAI.01094-13

Hanincova, K., Mukherjee, P., Ogden, N.H., Margos, G., Wormser, G.P., Reed, K.D., Meece, J.K., Vandermause, M.F., and Schwartz, I. (2013). Multilocus sequence typing of Borrelia burgdorferi suggests existence of lineages with differential pathogenic properties in humans. PLoS One 8, e73066. DOI: 10.1371/journal.pone.0073066

Hanincova, K., Kurtenbach, K., Diuk-Wasser, M., Brei, B., and Fish, D. (2006). Epidemic spread of Lyme borreliosis, northeastern United States. Emerg. Infect. Dis. 12, 604-611 DOI: 10.3201/eid1204.051016

Hart, T., Yang, X., Pal, U., and Lin, Y. (2018). Identification of Lyme borreliae proteins promoting vertebrate host blood-specific spirochete survival in Ixodes scapularis nymphs using artificial feeding chambers. Ticks and Tick-Borne Diseases 9, 1057-1063. DOl: 10.1016/j.ttbdis.2018.03.033

Haven, J., Vargas, L.C., Mongodin, E.F., Xue, V., Hernandez, Y., Pagan, P., Fraser-Liggett, C.M., Schutzer, S.E., Luft, B.J., Casjens, S.R., and Qiu, W.G. (2011). Pervasive recombination and sympatric genome diversification driven by frequency-dependent selection in Borrelia burgdorferi, the Lyme disease bacterium. Genetics 189, 951-966 DOI: 10.1534/genetics.111.130773

Herrmann, C., Gern, L., and Voordouw, M.J. (2013). Species cooccurrence patterns among Lyme borreliosis pathogens in the tick vector Ixodes ricinus. Appl. Environ. Microbiol. 79, 7273-7280 DOI: 10.1128/AEM.02158-13

Hersh, M.H., Ostfeld, R.S., McHenry, D.J., Tibbetts, M., Brunner, J.L., Killilea, M.E., LoGiudice, K., Schmidt, K.A., and Keesing, F. (2014). Co-infection of blacklegged ticks with Babesia microti and Borrelia burgdorferi is higher than expected and acquired from small mammal hosts. PloS One 9, e99348. DOI: 10.1371/journal.pone.0099348

Hildebrandt, A., Schmidt, K., Wilske, B., Dorn, W., Straube, E., and Fingerle, V. (2003). Prevalence of four species of Borrelia burgdorferi sensu lato and coinfection with Anaplasma phagocytophila in Ixodes ricinus ticks in central Germany. European Journal of Clinical 
Microbiology and Infectious Diseases 22, 364-367. DOI: 10.1007/ s10096-003-0926-2

Hoen, A.G., Margos, G., Bent, S.J., Diuk-Wasser, M.A., Barbour, A., Kurtenbach, K., and Fish, D. (2009). Phylogeography of Borrelia burgdorferi in the eastern United States reflects multiple independent Lyme disease emergence events. Proc. Natl. Acad. Sci. U. S. A. 106, 15013-15018 DOI: 10.1073/pnas.0903810106

Huang, Y.S., Higgs, S., and Vanlandingham, D.L. (2019). Arbovirusmosquito vector-host interactions and the impact on transmission and disease pathogenesis of arboviruses. Frontiers in Microbiology 10, 22. DOI: $10.3389 / \mathrm{fmicb} .2019 .00022$

Humphrey, P.T., Caporale, D.A., and Brisson, D. (2010). Uncoordinated phylogeography of Borrelia burgdorferi and its tick vector, Ixodes scapularis. Evolution: International Journal of Organic Evolution 64, 2653-2663. DOI: 10.1111/j.1558-5646.2010.01001.x

Jacquot, M., Gonnet, M., Ferquel, E., Abrial, D., Claude, A., Gasqui, P., Choumet, V., Charras-Garrido, M., Garnier, M., and Faure, B. (2014). Comparative population genomics of the Borrelia burgdorferi species complex reveals high degree of genetic isolation among species and underscores benefits and constraints to studying intra-specific epidemiological processes. PloS One 9, e94384. DOI: 10.1371/ journal.pone.0094384

Jones, C.G., Lawton, J.H., and Shachak, M. (1994). Organisms as ecosystem engineers. In Ecosystem management, Springer) pp. 130-147. DOI: 10.1007/978-1-4612-4018-1_14

Kenedy, M.R., Lenhart, T.R., and Akins, D.R. (2012). The role of Borrelia burgdorferi outer surface proteins. FEMS Immunology \& Medical Microbiology 66, 1-19. DOI: 10.1111/j.1574-695x.2012.00980.x

Khatchikian, C.E., Prusinski, M.A., Stone, M., Backenson, P.B., Wang, I., Foley, E., Seifert, S.N., Levy, M.Z., and Brisson, D. (2015). Recent and rapid population growth and range expansion of the Lyme disease tick vector, Ixodes scapularis, in North America. Evolution 69, 1678-1689. DOI: 10.1111/evo.12690

Kilpatrick, A.M., Dobson, A.D., Levi, T., Salkeld, D.J., Swei, A., Ginsberg, H.S., Kjemtrup, A., Padgett, K.A., Jensen, P.M., and Fish, D. (2017). Lyme disease ecology in a changing world: consensus, uncertainty and critical gaps for improving control. Philosophical Transactions of the Royal Society B: Biological Sciences 372, 20160117. DOI: 10.1098/rstb.2016.0117

Konnai, S., Yamada, S., Imamura, S., Nishikado, H., Githaka, N., Ito, T., Takano, A., Kawabata, H., Murata, S., and Ohashi, K. (2012). Identification of TROSPA homologue in Ixodes persulcatus Schulze, the specific vector for human Lyme borreliosis in Japan. Ticks and Tick-Borne Diseases 3, 75-77. DOI: 10.1016/j.ttbdis.2012.02.001

Kung, F., Anguita, J., and Pal, U. (2013). Borrelia burgdorferi and tick proteins supporting pathogen persistence in the vector. Future Microbiology 8, 41-56. DOI: 10.2217/fmb.12.121

Kurtenbach, K., Hanincová, K., Tsao, J.I., Margos, G., Fish, D., and Ogden, N.H. (2006). Fundamental processes in the evolutionary ecology of Lyme borreliosis. Nature Reviews Microbiology 4, 660-669. DOI: $10.1038 /$ nrmicro1475

Lagal, V., Portnoï, D., Faure, G., Postic, D., and Baranton, G. (2006). Borrelia burgdorferi sensu stricto invasiveness is correlated with OspC-plasminogen affinity. Microb. Infect. 8, 645-652. DOI: 10.1016/ j.micinf.2005.08.017

Lawrenz, M.B., Wooten, R.M., and Norris, S.J. (2004). Effects of vlsE complementation on the infectivity of Borrelia burgdorferi lacking the linear plasmid Ip28-1. Infect. Immun. 72, 6577-6585 DOI: 10.1128/IAI. 72.11.6577-6585.2004

Lescot, M., Audic, S., Robert, C., Nguyen, T.T., Blanc, G., Cutler, S.J., Wincker, P., Couloux, A., Claverie, J., and Raoult, D. (2008). The genome of Borrelia recurrentis, the agent of deadly louse-borne relapsing fever, is a degraded subset of tick-borne Borrelia duttonii. PLoS Genet 4, e1000185. DOI: 10.1371/journal.pgen.1000185
Lin, Y., Frye, A.M., Nowak, T.A., and Kraiczy, P. (2020). New insights into CRASP-Mediated complement evasion in the Lyme disease enzootic cycle. Frontiers in Cellular and Infection Microbiology 10, 1. DOI: 10.3389/fcimb.2020.00001

Livey, I., Gibbs, C., Schuster, R., and Dorner, F. (1995). Evidence for lateral transfer and recombination in OspC variation in Lyme disease Borrelia. Mol. Microbiol. 18, 257-269. DOI: 10.1111/j. 1365-2958.1995.mmi_18020257.x

Lloyd-Smith, J.O., George, D., Pepin, K.M., Pitzer, V.E., Pulliam, J.R., Dobson, A.P., Hudson, P.J., and Grenfell, B.T. (2009). Epidemic dynamics at the human-animal interface. Science 326, 1362-1367 DOI: 10.1126/science. 1177345

Marconi, R.T., Samuels, D.S., and Garon, C.F. (1993). Transcriptional analyses and mapping of the OSpC gene in Lyme disease spirochetes. J. Bacteriol. 175, 926-932 DOI: 10.1128/jb. 175.4.926-932.1993

Marcsisin, R.A., Lewis, E.R., and Barbour, A.G. (2016). Expression of the tick-associated Vtp protein of Borrelia hermsii in a murine model of relapsing fever. PloS One 11, e0149889. DOI: 10.1371/ journal.pone.0149889

Margos, G., Marosevic, D., Cutler, S., Derdakova, M., Diuk-Wasser, M., Emler, S., Fish, D., Gray, J., Hunfeldt, K., and Jaulhac, B. (2017). There is inadequate evidence to support the division of the genus Borrelia. Int. J. Syst. Evol. Microbiol. 67, 1081-1084. DOI: 10.1099/ ijsem.0.001717

Margos, G., Becker, N.S., Fingerle, V., Sing, A., Ramos, J.A., de Carvalho, I.L., and Norte, A.C. (2019). Core genome phylogenetic analysis of the avian associated Borrelia turdi indicates a close relationship to Borrelia garinii. Mol. Phylogenet. Evol. 131, 93-98. DOI: 10.1016/j.ympev.2018.10.044

Margos, G., Fingerle, V., Cutler, S., Gofton, A., Stevenson, B., and Estrada-Peña, A. (2020). Controversies in bacterial taxonomy: The example of the genus Borrelia. Ticks and Tick-Borne Diseases 11, 101335. DOI: 10.1016/j.ttbdis.2019.101335

Margos, G., Fingerle, V., and Reynolds, S.E. (2019). Borrelia bavariensis: vector switch, niche invasion and geographical spread of a tick-borne bacterial parasite. Frontiers in Ecology and Evolution 7, 401. DOI: $10.3389 / \mathrm{fev} 0.2019 .00401$

Margos, G., Vollmer, S.A., Ogden, N.H., and Fish, D. (2011). Population genetics, taxonomy, phylogeny and evolution of Borrelia burgdorferi sensu lato. Infection, Genetics and Evolution 11, 1545-1563. DOI: 10.1016/j.meegid.2011.07.022

Margos, G., Vollmer, S.A., Cornet, M., Garnier, M., Fingerle, V., Wilske, B., Bormane, A., Vitorino, L., Collares-Pereira, M., Drancourt, M., and Kurtenbach, K. (2009). A new Borrelia species defined by multilocus sequence analysis of housekeeping genes. Appl. Environ. Microbiol. 75, 5410-5416 DOI: 10.1128/AEM.00116-09

McCoy, K. D., Leger, E., and Dietrich, M. (2013). Host specialization in ticks and transmission of tick-borne diseases: A review. Frontiers in Cellular and Infection Microbiology 3: 12 DOI: 10.3389/fcimb. 2013.00057

Mechai, S., Margos, G., Feil, E.J., Barairo, N., Lindsay, L.R., Michel, P., and Ogden, N.H. (2016). Evidence for host-genotype associations of Borrelia burgdorferi sensu stricto. PLoS One 11, e0149345. DOI: 10.1371/journal.pone. 0149345

Moutailler, S., Valiente Moro, C., Vaumourin, E., Michelet, L., Tran, F.H., Devillers, E., Cosson, J., Gasqui, P., Van, V.T., and Mavingui, P. (2016). Co-infection of ticks: the rule rather than the exception. PLoS Neglected Tropical Diseases 10, e0004539. DOI: 10.1371/ journal.pntd.0004539

Neelakanta, G., Li, X., Pal, U., Liu, X., Beck, D.S., DePonte, K., Fish, D., Kantor, F.S., and Fikrig, E. (2007). Outer surface protein B is critical for Borrelia burgdorferi adherence and survival within Ixodes ticks. PLoS Pathog 3, e33. DOI: 10.1371/journal.ppat.0030033 
Norris, S.J. (2015). vls antigenic variation systems of Lyme disease Borrelia: eluding host immunity through both random, segmental gene conversion and framework heterogeneity. Mobile DNA III 471-489. DOI: $10.1128 / 9781555819217 . c h 22$

Norris, S.J., Howell, J.K., Garza, S.A., Ferdows, M.S., and Barbour, A.G. (1995). High- and low-infectivity phenotypes of clonal populations of in vitro-cultured Borrelia burgdorferi. Infect. Immun. 63, 2206-2212 DOI: 10.1128/IAl.63.6.2206-2212.1995

Norte, A.C., Margos, G., Becker, N.S., Albino Ramos, J., Núncio, M.S., Fingerle, V., Araújo, P.M., Adamík, P., Alivizatos, H., and Barba, E. (2020). Host dispersal shapes the population structure of a tickborne bacterial pathogen. Mol. Ecol. 29, 485-501. DOI: 10.1111/mec. 15336

Ogden, N.H., Feil, E.J., Leighton, P.A., Lindsay, L.R., Margos, G., Mechai, S., Michel, P., and Moriarty, T.J. (2015). Evolutionary aspects of emerging Lyme disease in Canada. Appl. Environ. Microbiol. 81, 7350-7359 DOI: 10.1128/AEM.01671-15

Ojaimi, C., Brooks, C., Casjens, S., Rosa, P., Elias, A., Barbour, A., Jasinskas, A., Benach, J., Katona, L., Radolf, J., et al. (2003). Profiling of temperature-induced changes in Borrelia burgdorferi gene expression by using whole genome arrays. Infect. Immun. 71, 1689-1705 DOI: 10.1128/IAl.71.4.1689-1705.2003

Önder, Ö., Humphrey, P.T., McOmber, B., Korobova, F., Francella, N., Greenbaum, D.C., and Brisson, D. (2012). OspC is potent plasminogen receptor on surface of Borrelia burgdorferi. J. Biol. Chem. 287, 16860-16868 DOI: 10.1074/jbc.M111.290775

Pal, U., Li, X., Wang, T., Montgomery, R.R., Ramamoorthi, N., DeSilva, A.M., Bao, F., Yang, X., Pypaert, M., and Pradhan, D. (2004). TROSPA, an Ixodes scapularis receptor for Borrelia burgdorferi. Cell 119, 457-468. DOI: 10.1016/j.cell.2004.10.027

Pal, U., Montgomery, R.R., Lusitani, D., Voet, P., Weynants, V., Malawista, S.E., Lobet, Y., and Fikrig, E. (2001). Inhibition of Borrelia burgdorferi-tick interactions in vivo by outer surface protein $A$ antibody. J. Immunol. 166, 7398-7403 DOI: 10.4049/jimmunol. 166.12 .7398

Parker, J.L., and White, K.K. (1992). Lyme borreliosis in cattle and horses: a review of the literature. Cornell Vet. 82, 253-274.

Paul, R.E., Cote, M., Le Naour, E., and Bonnet, S.I. (2016). Environmental factors influencing tick densities over seven years in a French suburban forest. Parasites \& Vectors 9, 309. DOI: 10.1186/ s13071-016-1591-5

Phelan, J.P., Kern, A., Ramsey, M.E., Lundt, M.E., Sharma, B., Lin, T., Gao, L., Norris, S.J., Hyde, J.A., and Skare, J.T. (2019). Genomewide screen identifies novel genes required for Borrelia burgdorferi survival in its Ixodes tick vector. PLoS Pathogens 15, e1007644. DOI: 10.1371/journal.ppat.1007644

Popitsch, N., Bilusic, I., Rescheneder, P., Schroeder, R., and Lybecker, M. (2017). Temperature-dependent sRNA transcriptome of the Lyme disease spirochete. BMC Genomics 18, 28. DOI: 10.1186/ s12864-016-3398-3

Preac-Mursic, V., Wilske, B., Jauris, S., Will, G., Reinhardt, S., Lehnert, G., Patsouris, E., Mehraein, P., Soutschek, E., and Klockmann, U. (1992). Active immunization with pC protein of Borrelia burgdorferi protects gerbils against $B$. burgdorferi infection. Infection 20, 342-349. DOI: 10.1007/BF01710681

Pritt, B.S., Mead, P.S., Johnson, D.K.H., Neitzel, D.F., Respicio-Kingry, L.B., Davis, J.P., Schiffman, E., Sloan, L.M., Schriefer, M.E., and Replogle, A.J. (2016). Identification of a novel pathogenic Borrelia species causing Lyme borreliosis with unusually high spirochaetaemia: a descriptive study. The Lancet Infectious Diseases 16, 556-564. DOI: 10.1016/S1473-3099(15)00464-8

Probert, W.S., Crawford, M., Cadiz, R.B., and LeFebvre, R.B. (1997). Immunization with outer surface protein (Osp) A, but not OspC, provides cross-protection of mice challenged with North American isolates of Borrelia burgdorferi. J. Infect. Dis. 175, 400-405. DOI: 10.1093/infdis/175.2.400

Radolf J.D. and Samuels, D.S. (2021). Lyme Disease and Relapsing Fever Spirochetes: Genomics, Molecular Biology, Host Interactions and Disease Pathogenesis (Norfolk, UK: Caister Academic Press). https://doi.org/10.21775/9781913652616

Rego, R.O., Bestor, A., Štefka, J., and Rosa, P.A. (2014). Population bottlenecks during the infectious cycle of the Lyme disease spirochete Borrelia burgdorferi. PLoS One 9, e101009. DOI: 10.1371/ journal.pone.0101009

Ripoche, J., Day, A., Harris, T.J., and Sim, R. (1988). The complete amino acid sequence of human complement factor $\mathrm{H}$. Biochem. J. 249, 593-602. DOI: 10.1042/bj2490593

Roberts, E.D., Bohm Jr, R.P., Lowrie Jr, R.C., Habicht, G., Katona, L., Piesman, J., and Philipp, M.T. (1998). Pathogenesis of Lyme neuroborreliosis in the rhesus monkey: the early disseminated and chronic phases of disease in the peripheral nervous system. J. Infect. Dis. 178, 722-732. DOI: 10.1086/515357

Rollend, L., Fish, D., and Childs, J.E. (2013). Transovarial transmission of Borrelia spirochetes by Ixodes scapularis: a summary of the literature and recent observations. Ticks and Tick-Borne Diseases 4 , 46-51. DOI: 10.1016/j.ttbdis.2012.06.008

Ross, B.D., Hayes, B., Radey, M.C., Lee, X., Josek, T., Bjork, J., Neitzel, D., Paskewitz, S., Chou, S., and Mougous, J.D. (2018). Ixodes scapularis does not harbor a stable midgut microbiome. The ISME Journal 12, 2596-2607. DOI: 10.1038/s41396-018-0161-6

Saarinen, K., Laakso, J., Lindström, L., and Ketola, T. (2018). Adaptation to fluctuations in temperature by nine species of bacteria. Ecology and Evolution 8, 2901-2910. DOI: 10.1002/ece3.3823

Seifert, S.N., Khatchikian, C.E., Zhou, W., and Brisson, D. (2015). Evolution and population genomics of the Lyme borreliosis pathogen, Borrelia burgdorferi. Trends in Genetics 31, 201-207. DOI: 10.1016/ j.tig.2015.02.006

Shih, C. M., Telford, S. R., and Spielman, A. (1995). Effect of ambient temperature on competence of deer ticks as hosts for Lyme disease spirochetes. Journal of clinical microbiology, 33: 958-961. DOI: 10.1128/JCM.33.4.958-961.1995

Šimo, L., Kazimirova, M., Richardson, J., and Bonnet, S.I. (2017). The essential role of tick salivary glands and saliva in tick feeding and pathogen transmission. Frontiers in Cellular and Infection Microbiology 7, 281. DOI: 10.3389/fcimb.2017.00281

Sonenshine, D. (1979). Ticks of Virginia. Virginia Polytechnic Institute and State University, College of Agriculture and Life Sciences, Blacksburg, VA 42.

Stanek, G., Wormser, G.P., Gray, J., and Strle, F. (2012). Lyme borreliosis. The Lancet 379, 461-473. DOI: 10.1016/ S0140-6736(11)60103-7

Susi, H., Barrès, B., Vale, P.F., and Laine, A. (2015). Co-infection alters population dynamics of infectious disease. Nature Communications 6 , 1-8. DOI: 10.1038/ncomms6975

Talagrand-Reboul, E., Boyer, P.H., Bergström, S., Vial, L., and Boulanger, N. (2018). Relapsing fevers: neglected tick-borne diseases. Frontiers in Cellular and Infection Microbiology 8, 98. DOI: 10.3389/fcimb.2018.00098

Taylor, L.H., Latham, S.M., and Woolhouse, M.E. (2001). Risk factors for human disease emergence. Philosophical Transactions of the Royal Society of London.Series B: Biological Sciences 356, 983-989. DOI: 10.1098/rstb.2001.0888

Telfer, S., Lambin, X., Birtles, R., Beldomenico, P., Burthe, S., Paterson, S., and Begon, M. (2010). Species interactions in a parasite community drive infection risk in a wildlife population. Science 330, 243-246 DOI: 10.1126/science.1190333

Tokarz, R., Anderton, J.M., Katona, L.I., and Benach, J.L. (2004). Combined effects of blood and temperature shift on Borrelia burgdorferi gene expression as determined by whole genome DNA 
array. Infect. Immun. 72, 5419-5432 DOI: 10.1128/IAI. 72.9.5419-5432.2004

Trape, J., Diatta, G., Arnathau, C., Bitam, I., Sarih, M., Belghyti, D., Bouattour, A., Elguero, E., Vial, L., and Mane, Y. (2013). The epidemiology and geographic distribution of relapsing fever borreliosis in West and North Africa, with a review of the Ornithodoros erraticus complex (Acari: Ixodida). PLoS One 8, e78473. DOl: 10.1371/journal.pone.0078473

Tufts, D.M., Hart, T.M., Chen, G.F., Kolokotronis, S., Diuk-Wasser, M.A., and Lin, Y. (2019). Outer surface protein polymorphisms linked to host-spirochete association in Lyme borreliae. Mol. Microbiol. 111, 868-882. DOI: $10.1111 / \mathrm{mmi} .14209$

Van Treuren, W., Ponnusamy, L., Brinkerhoff, R.J., Gonzalez, A., Parobek, C.M., Juliano, J.J., Andreadis, T.G., Falco, R.C., Ziegler, L.B., Hathaway, N., et al. (2015). Variation in the microbiota of Ixodes ticks with regard to geography, species, and sex. Appl. Environ. Microbiol. 81, 6200-6209 DOI: 10.1128/AEM.01562-15

Vial, L. (2009). Biological and ecological characteristics of soft ticks (Ixodida: Argasidae) and their impact for predicting tick and associated disease distribution. Parasite 16, 191-202. DOI: 10.1051/ parasite/2009163191

Vial, L., Durand, P., Arnathau, C., Halos, L., Diatta, G., Trape, J., and Renaud, F. (2006). Molecular divergences of the Ornithodoros sonrai soft tick species, a vector of human relapsing fever in West Africa. Microb. Infect. 8, 2605-2611. DOI: 10.1016/j.micinf.2006.07.012

Vitorino, L.R., Margos, G., Feil, E.J., Collares-Pereira, M., Ze-Ze, L., and Kurtenbach, K. (2008). Fine-scale phylogeographic structure of Borrelia lusitaniae revealed by multilocus sequence typing. PLoS One 3, e4002. DOI: 10.1371/journal.pone.0004002

Vollmer, S.A., Bormane, A., Dinnis, R.E., Seelig, F., Dobson, A.D., Aanensen, D.M., James, M.C., Donaghy, M., Randolph, S.E., and Feil, E.J. (2011). Host migration impacts on the phylogeography of Lyme Borreliosis spirochaete species in Europe. Environ. Microbiol. 13, 184-192. DOI: 10.1111/j.1462-2920.2010.02319.x

Vollmer, S.A., Feil, E.J., Chu, C., Raper, S.L., Cao, W., Kurtenbach, K. and Margos, G. (2013). Spatial spread and demographic expansion of Lyme borreliosis spirochaetes in Eurasia. Infection, Genetics and Evolution 14, 147-155. DOI: 10.1016/j.meegid.2012.11.014

Vuong, H.B., Chiu, G.S., Smouse, P.E., Fonseca, D.M., Brisson, D., Morin, P.J., and Ostfeld, R.S. (2017). Influences of host community characteristics on Borrelia burgdorferi infection prevalence in blacklegged ticks. PloS One 12, e0167810. DOI: 10.1371/ journal.pone. 0167810

Walter, K.S., Carpi, G., Caccone, A., and Diuk-Wasser, M.A. (2017). Genomic insights into the ancient spread of Lyme disease across North America. Nature Ecology \& Evolution 1, 1569-1576. DOI: 10.1038/s41559-017-0282-8

Walter, K.S., Carpi, G., Evans, B.R., Caccone, A., and Diuk-Wasser, M.A. (2016). Vectors as epidemiological sentinels: patterns of withintick Borrelia burgdorferi diversity. PLoS Pathogens 12, e1005759. DOI: 10.1371/journal.ppat.1005759

Wang, G., Ojaimi, C., Wu, H., Saksenberg, V., lyer, R., Liveris, D., McClain, S.A., Wormser, G.P., and Schwartz, I. (2002). Disease severity in a murine model of Lyme borreliosis is associated with the genotype of the infecting Borrelia burgdorferi sensu stricto strain. J. Infect. Dis. 186, 782-791. DOI: 10.1086/343043

Wang, G., Ojaimi, C., Iyer, R., Saksenberg, V., McClain, S.A., Wormser, G.P., and Schwartz, I. (2001). Impact of genotypic variation of Borrelia burgdorferi sensu stricto on kinetics of dissemination and severity of disease in $\mathrm{C} 3 \mathrm{H} / \mathrm{HeJ}$ mice. Infect. Immun. 69, 4303-4312 DOI: 10.1128/IAI.69.7.4303-4312.2001

Wilske, B., Fingerle, V., Herzer, P., Hofmann, A., Lehnert, G., Peters, H., Pfister, H., Preac-Mursic, V., Soutschek, E., and Weber, K. (1993). Recombinant immunoblot in the serodiagnosis of Lyme borreliosis. Med. Microbiol. Immunol. 182, 255-270. DOI: 10.1007/BF00579624

Wormser, G.P., Brisson, D., Liveris, D., Hanincová, K., Sandigursky, S., Nowakowski, J., Nadelman, R.B., Ludin, S., and Schwartz, I. (2008). Borrelia burgdorferi genotype predicts the capacity for hematogenous dissemination during early Lyme disease. J. Infect. Dis. 198, 1358-1364. DOI: 10.1086/592279

Zhang, D., de Souza, R.F., Anantharaman, V., Iyer, L.M., and Aravind, L. (2012). Polymorphic toxin systems: comprehensive characterization of trafficking modes, processing, mechanisms of action, immunity and ecology using comparative genomics. Biology Direct 7, 18. DOI: 10.1186/1745-6150-7-18

Zhang, J.R., and Norris, S.J. (1998). Kinetics and in vivo induction of genetic variation of vIsE in Borrelia burgdorferi. Infect. Immun. 66, 3689-3697 DOI: 10.1128/IAI.66.8.3689-3697.1998

Zolnik, C.P., Prill, R.J., Falco, R.C., Daniels, T.J., and Kolokotronis, S. (2016). Microbiome changes through ontogeny of a tick pathogen vector. Mol. Ecol. 25, 4963-4977. DOl: 10.1111/mec.1383 
